\title{
Gilles Roques, Chrétien de Troyes, des manuscrits aux éditions
}

\section{Maria Colombo Timelli}

\section{(2) OpenEdition}

1 Journals

Édition électronique

URL : http://journals.openedition.org/studifrancesi/6527

DOI : ERREUR PDO dans /localdata/www-bin/Core/Core/Db/Db.class.php L.34 : SQLSTATE[HY000]

[2006] MySQL server has gone away

ISSN : 2427-5856

\section{Éditeur}

Rosenberg \& Sellier

Édition imprimée

Date de publication : 1 septembre 2010

Pagination : 332

ISSN : 0039-2944

\section{Référence électronique}

Maria Colombo Timelli, « Gilles Roques, Chrétien de Troyes, des manuscrits aux éditions », Studi Francesi [En ligne], 161 (LIV | II) | 2010, mis en ligne le 30 novembre 2015, consulté le 07 janvier 2021. URL:

http://journals.openedition.org/studifrancesi/6527 ; DOI : https://doi.org/10.4000/studifrancesi.6527

Ce document a été généré automatiquement le 7 janvier 2021.

\section{(c) $(1)$}

Studi Francesi è distribuita con Licenza Creative Commons Attribuzione - Non commerciale - Non opere derivate 4.0 Internazionale. 


\title{
Gilles Roques, Chrétien de Troyes, des manuscrits aux éditions
}

\author{
Maria Colombo Timelli
}

\section{RÉFÉRENCE}

GILLES RoQUes, Chrétien de Troyes, des manuscrits aux éditions, dans «Medioevo Romanzo», XXXIII, 2009, pp. 5-27.

Après un intéressant panoramique des éditions des romans de Chrétien, où sont évoqués entre autres le contexte qui a vu paraître les éditions fondatrices de Wendelin Foerster et les relations parfois orageuses de celui-ci avec Gaston Paris, G.R. s'attache à la question capitale de la langue de Chrétien, difficile à cerner derrière les choix et les interventions des copistes. Il relève en particulier la présence de quelques mots de l'Ouest qui doivent remonter à l'auteur, pour passer ensuite à une analyse détaillée des variantes aux vv. 1526-92 de Cligés, éd. Luttrell-Gregory (1532-98 de Foerster). M. Roques montre ainsi tout l'intérêt qu'il y aurait à étendre une telle collation à l'ensemble de la production de Chrétien, ce qui permettrait de mieux approcher la langue de l'auteur, au-delà des copies et surtout de la copie trop célébrée de Guiot, qui demeure au centre de la réflexion même des éditeurs qui ne fondent pas leur texte sur ce manuscrit. 